\title{
PENANAMAN NILAI-NILAI DASAR ISLAMI ANAK USIA DINI PADA MASYARAKAT PERKOTAAN
}

\author{
ISYATUL MARDIYATI
}

\author{
Penulis adalah dosen PGRA Fakultas Tarbiyah dan Ilmu Keguruan (FTIK) \\ Institut Agama Islam Negeri (IAIN) Pontianak
}

\begin{abstract}
Negative Social phenomena in urban society due to changes in lifestyle, social interaction, and changes in social systems have led to problems in many aspects of life. The social problems indicate that urban community is going through a phase of 'demoralization' as a result of social changes that are not in line with the Islamic basic values and other norms. The increasing cases of crime in urban areas in terms of quality and quantity, such as corruption, fraud, theft, assault, murder, etc. indicate that the quality of the character and behavior of individuals or groups are still low, resulting from insufficient religious education and norms they receive from an early age.

In this light, the Kindergarten or Early Childhood Education plays a very important role in instilling basic Islamic values in children from an early age. The efforts can be made through a series of activities of 'play and learn' to actualize Islamic values in everyday life. These activities are expected to achieve a better generation in terms of mental and intellectual capacities, having noble character and strong faith as well as piety to Allah. In addition, through instillation of basic Islamic values from an early age, we will have a new generation of Muslims who act as agents of change that bring about the glory of Islam in the modern era.
\end{abstract}

Keywords: Basic Islamic values, early childhood and urban community, phase of demoralization

\section{PENDAHULUAN}

Di zaman yang serba modern sekarang ini, masyarakat perkotaan dihadapkan pada realita kehidupan sosial yang cepat mengalami perubahan. Kemajuan teknologi informasi dan komunikasi, serta terintegrasinya sarana transportasi antara satu wilayah dengan wilayah lainnya, mendorong pergeseran nilai-nilai dasar dan norma-norma yang berlaku di masyarakat. Dalam kesempatan ini, posisi orangtua kemudian dihadapkan pada dua pilihan, yakni menyerah dengan mengikuti berbagai perubahan yang terjadi atau melawan dengan mempertahankan nilai-nilai yang telah berlaku dimasa lampau dan oleh utusan-utusan Tuhan.

Tidak dapat dipungkiri, suatu perubahan yang terjadi pada masyarakat modern di perkotaan tidak selalu berimplikasi positif, karena sebagian diantaranya justru sering kali menyimpang dari nilai-nilai dasar agama. Bahkan diantara berbagai perubahan tersebut menjurus ke arah kriminal yang dapat merugikan dirinya sendiri maupun orang lain. Berbagai prilaku penyimpangan tersebut dapat ditemukan pada individu atau kelompok orang yang berakhlak rendah dan berperilaku rusak yang tinggal menetap di wilayah 
perkotaan. Mereka tidak hanya didominasi oleh kaum pinggiran (marginal) tetapi juga berasal dari berbagai stratifikasi sosial. Bahkan diantara mereka adalah pejabat tinggi negara, tokoh masyarakat, sampai warga perkotaan biasa. Penyimpangan yang terjadi pada masyarakat perkotaan bersifat multidimensional yang tidak terbatas pada usia, jenis kelamin ataupun startifikasi sosial tertentu.

Seiring dengan pergeseran nilai dan norma sosial masyarakat di perkotaan, kehidupan keluarga juga terkena dampak yang cukup signifikan. Orangtua dengan berbagai alasan dinamika kerja serta persoalan lainnya, kemudian berangsur-angsur mengurangi perannya dalam lembaga kehidupan keluarga. Hal ini kemudian berpengaruh pada perkembangan usia dan pendidikan anak, khususnya yang masih berada dalam usia dini. Keprihatinan semakin bertambah, manakala anak usia dini saat ini sudah dihadapkan pada kemajuan teknologi intenet dan tayangan-tayangan yang sebagian besar sudah tidak sesuai dengan usia perkembangan dan pembentukan kepribadiannya. Miskinnya figur super hero di dunia nyata sebagai suri tauladan bagi anak serta berkurangnya legenda-legenda seniman yang berkarya untuk anak yang ditandai dengan tutup usianya Drs. Suryadi atau yang lebih populer dengan sebutan Pak Raden, pada jum'at, 30 Oktober 2015, menjadikan anakanak di perkotaan cenderung menjadi 'anak dewasa sejak dini' dengan kata lain dewasa prematur atau dewasa sebelum waktunya. Dari persoalan ini, tampak jelas bahwa produk-produk budaya tradisional sebenarnya sudah tidak mampu untuk menandingi kemampuan media internet, televisi dan produk globalisasi lainnya dalam menyentuh dan mempengaruhi psikis anak dalam berpikir, bertindak dan berperilaku.

Waktu bangun anak usia dini dalam keluarga perkotaan lebih banyak dihabiskan bersama pembantu rumah tangga, baby sitter atau berada pada lembaga pendidikan nonformal, seperti: tempat penitipan anak, play group. Bahkan diantara mereka ditempatkan pada lembaga formal prasekolah seperti Taman Kanak-Kanak (TK) atau Pendidikan Anak Usia dini (PAUD) yang bersifat full day school. Sedangkan waktu tidur atau non aktifnya anak justru dihabiskan dengan tinggal di rumah yang hampir tanpa interaksi dengan orangtua karena disebabkan lelah selama beraktifitas di sekolah. Dengan demikian, dapat dipastikan bahwa sebagian besar anak usia dini pada keluarga perkotaan tidak dapat sehari penuh merasakan kebersamaan dengan orangtua, sebagai dampak dari kesibukan orangtua yang bekerja di luar rumah.

Dari persoalan tersebut, orangtua semakin menyadari bahwa pendidikan merupakan salah satu kebutuhan pokok yang amat mendasar bagi anak-anak. Pendidikan bagi anak di usia dini merupakan hal yang tidak bisa ditawar-tawar. Oleh sebab itu, tidak mengherankan jika semakin banyak orangtua yang merasa perlu untuk segera memasukkan anak-anaknya ke sekolah sejak usia dini yang mampu mengintegrasikan antara iman dan ilmu pengetahuan modern. Disini mereka berharap agar anak-anak yang mereka miliki akan dapat segera lepas dari ketergantungannya terhadap orangtua, namun tetap memiliki dasar agama dan science yang baik.

Salah satu riwayatnya yang cukup populer di masyarakat, menyatakan ;

Barangsiapa menghendaki kebahagian di dunia, hendaklah berilmu. Barang siapa menghendaki akhirat hendaklah berilmu. Dan barang siapa menghendaki keduanya hendaklah berilmu. ${ }^{1}$

1 Akhmad Faozan. 500 Kelalaian dalam Shalat. (Ja- 
Berdasarkan penjelasan tersebut, ilmu adalah syarat bagi seseorang untuk mendapatkan kesuksesan dunia maupun di akhirat, dan ilmu juga merupakan hal yang tidak dapat dipisahkan atau dikelompok-kelompokan satu sama lain baik antara iman, Islam maupun ihsan. Dengan kata lain kualitas dan ilmu agama tidak dapat dipisahkan, sebagaimana hadits Rasulullah SAW, yang artinya : " $\mathrm{Ba}$ rang siapa yang dikehendaki Allah dengan kebaikan, Allah akan memantapkan ilmu agamanya". ${ }^{2}$

\section{PENDIDIKAN PADA ANAK USIA DINI (PAUD) DAN PENANAMAN NILAI-NILAI DASAR ISLAMI}

\section{Anak Usia Dini dan Pendidikan Anak Usia Dini (PAUD)}

Anak adalah generasi penerus yang kelak akan mewarisi kepemimpinan dibidang keagamaan, kebangsaan dan kenegaraan. Undang-Undang Nomor 23 Tahun 2002 tentang Perlindungan Anak (dalam Maria dan Abdullah, 2010) menyatakan bahwa yang dimaksud dengan anak adalah seseorang yang belum berusia 18 tahun, termasuk yang masih di dalam kandungan. ${ }^{3}$ Bagi anak-anak yang tinggal dalam keluarga dan keluarga tinggal di dalam lingkungan bertetangga dan komunitas masyarakat yang lebih luas, akan terbentuk suatu kemitraan yang muncul dari respon hubungan antara anak, orangtua dan masyarakat.

Rentangan anak usia dini yang dimaksud dalam penulisan ini mengacu pada Pasal

karta : Qultum Media. 2009). hlm. 3-4.

2 Danial Zainal Abidin. Al-Qur'an for Life Exellence: Tips-Tips Cemerlang dari Al-Qur'an. (Jakarta. PT. Mizan Publika, 2007). hlm. 131.

3 Maria Ulfah Anshor \& Abdullah Ghalib. Parenting With Love : Panduan Islami Mendidik Anak Penuh Cinta dan Kasih Sayang. (Jakarta: PT. Mizan Pustaka, 2010). hlm. -
28 UU Sisdiknas No.20/2003 ayat 1 adalah mereka yang berada antara usia 0 - 6 tahun. Meskipun dalam kajian rumpun keilmuan PAUD dan prkatik penyelenggaraannya di beberapa negara, pendidikan anak usia dini dilaksanakan sejak anak berada pada rentangan usia 0 - 8 tahun. Selain itu, Jane Brooks (2011) menyebutkan bahwa anak adalah 1) individu yang belum berpengalaman dan bergantung pada orangtua. 2) Diharapkan mengikuti aturan dan permintaan orang tua, 3) dianggap tidak mampu memutuskan sehingga sebelum anak berusia 18 tahun, orang tua harus memberikan izin atas perawatan medis rutin, izin mengemudi, memasuki dinas militer dan pernikahan. ${ }^{4}$ Lebih lanjut, Jane Brooks (2011) juga menyatakan bahwa orangtua menginvestasikan waktu, emosi, energi dan uang dalam membesarkan anak. Mereka ingin apa yang mereka lakukan bermanfaat bagi kehidupan anak sehingga pengorbanan yang mereka lakukan dapat membantu anak untuk tumbuh. ${ }^{5}$

Fakta yang ditemukan oleh ahli-ahli Neurologi yang menyatakan bahwa pada saat lahir otak bayi mengandung 100 sampai 200 milyar neuron atau sel syaraf yang siap melakukan sambungan antar sel. Sekitar 50\% kapasitas kecerdasan manusia telah terjadi ketika usia 4 tahun, 80\% telah terjadi ketika berusia 8 tahun, dan mencapai titik kulminasi $100 \%$ ketika anak berusia 8 sampai 18 tahun. Pertumbuhan fungsional sel-sel syaraf tersebut membutuhkan berbagai situasi pendidikan yang mendukung, baik dalam pendidikan keluarga, masyarakat maupun sekolah. Para ahli pendidikan sepakat bahwa periode keemasan tersebut hanya berlangsung satu

4 Jane Brooks. The Process of Parenting. Terj. Rahmat Fajar. (Yogyakarta: Pustaka Pelajar. 2011). hlm $18-19$.

5 Jane Brooks. Ibid. hlm. 32. 
kali sepanjang rentang kehidupan manusia. Hal ini menunjukkan bahwa betapa meruginya suatu keluarga, masyarakat dan bangsa jika mengabaikan masa-masa penting yang berlangsung pada anak usia dini.

Sebagai komitmen dan keseriusan antar bangsa terhadap pendidikan anak usia dini telah dicapai berbagai momentum dan kesepakatan penting yang telah digalang secara internasional. Salah satunya adalah Deklarasi Dakkar yang diantaranya menyepakati bahwa perlunya upaya memperluas dan memperbaiki keseluruhan perawatan dan pendidikan anak usia dini, terutama bagi anak-anak yang sangat rawan dan kurang beruntung. Adapun komitmen antara bangsa secara internasional lainnya adalah kesepakatan antar negara yang tergabung dalam Perserikatan Bangsa-Bangsa yang menyepakati "Dunia yang layak bagi anak 2002" atau dikenal dengan "world fit for children 2002". Beberapa kesepakatan yang diperoleh adalah (1) mencanangkan kehidupan yang sehat, (2) memberikan pendidikan yang berkualitas, (3) memberikan perlindungan terhadap penganiayaan, eksploitasi dan kekerasan

Dalam rangka membantu memenuhi kebutuhan anak usia dini pada bidang pendidikan, pemerintah berusaha menfasilitasi dengan dikembangkannya Kurikulum PAUD yang diharapkan dapat membantu memberikan pendidikan yang berkualitas pada anak usia dini. Dengan rujukan kurikulum ini diharapkan dapat membantu lembaga pendidikan keluarga (informal), lembaga pendidikan masyarakat (non formal) dan lembaga pendidikan anak usia dini formal (TK/RA) dalam memperoleh akses konsep kurikulum anak usia dini.

Kurikulum PAUD dibutuhkan dalam rangka memenuhi kebutuhan perkembangan (standar performance) anak pada segala as- pek perkembangan sehingga dapat membantu mempersiapkan anak beradaptasi secara kreatif dengan lingkungan masa kini dan masa depan. Kurikulum PAUD yang menjadi rujukan sebagian besar TK/RA, KB, dan TPA saat ini adalah Kurikulum 2004 Standar Kompetensi TK/RA (dari Direktorat TK/SD), Menu Pembelajaran Generik (dari Direktorat PAUD), Pedoman Pengembangan Silabus untuk TK/RA, Pedoman Pembelajaran untuk TK/RA, dan Pedoman Penilaian. Di samping itu lapangan juga diperkenalkan dengan draft Kerangka Dasar Kurikulum PAUD dan Standar Perkembangan Anak Lahir s.d 6 tahun. Hingga saat ini belum ditetapkan Standar Nasional Pendidikan (8 Standar) untuk PAUD. Untuk itu perlu dilakukan kegiatan Kajian Kebijakan Kurikulum PAUD yang meliputi kajian pelaksanaan kurikulum PAUD di lapangan dan kajian dokumen serta kajian teoritis berbagai landasan keilmuan yang dapat mendasari atau menjadi pijakan Pendidikan Anak Usia Dini. Hasil kajian ini berupa "Naskah Akademik" yang diharapkan menjadi masukan dalam merumuskan Standar Nasional Pendidikan untuk PAUD yang berkaitan dengan Standar Kompetensi Lulusan (untuk anak usia dini disebut Standar Kompetensi Akhir Usia), Standar Isi (Standar Kompetensi Perkembangan atau Standar Perkembangan), Standar Proses, Standar Penilaian, Standar Pendidik dan Tenaga Kependidikan PAUD, Standar Sarana dan Prasarana, Standar Pengelolaan dan Standar Pembiayaan.

Walapun berbagai upaya secara konseptual maupun praktis telah diupayakan dalam membangun anak usia dini namun masih banyak anak usia dini di Indonesia yang belum terlayani kebutuhannya pada bidang pendidikan (sensus BPS terbaru 2005 mencapai 26 juta). Pada sisi lain, kelembagaan pendidikan anak usia dini yang ada baru dapat 
menampung sebesar 27\% Angka Partisipasi Kasar (APK). Hal ini diperburuk dengan masih rendahnya kualitas penyelenggaraan lembaga pendidikan anak usia dini yang dilihat dari aspek standar program yang diberikan, proses pembelajaran yang belum meng akomodasi kebutuhan anak dan kualitas serta kualifikasi tenaga pendidik anak usia dini yang masih tergolong rendah.

Terkait dengan pendidikan anak usia dini yang telah dilangsungkan di lembaga formal, seperti Taman Kanak-Kanak maupun PAUD, dapat diketahui bahwa ternyata sejarah Islam sudah mengenal hal tersebut sejak pemerintahan Amirul Mukminin, Saidina Umar bin Al-Khattab r.a. berkuasa (634 Masehi - 644 Masehi). Hal ini dapat dilihat dari pernyataan Umar bin Al-Khattab r.a. (dalam Fauzul Na'im Ishak, 2005: 521) yang menyatakan "ajarkanlah anak-anakmu memanah, berenang dan menunggang kuda". ${ }^{6}$ Namun konsep pendidikan yang ada dimasa Umar bin Khatab dikala itu, masih terpaku pada pendidikan anak yang berada di dalam masjid serta kurikulum pendidikan bagi anak yang masih sederhana dan terbatas pada pengenalan baca tulis serta hafalan-hafalan surah dalam al-Qur'an. Baru di zaman Utsman bin Affan berkuasa (644 Masehi - 656 Masehi) lembaga pendidikan seperti kuttab/maktab mulai dibentuk dan kemudian berkembang di masa Daulah Umayyah sampai akhirnya Islam kemudian berhasil membentuk madrasah bahkan universitas pertama di dunia yang bernama al-Qarawiyyin, Maroko tahun 859 Masehi.

Adapun Pendidikan Anak Usia Dini atau yang populer dengan istilah kindergarten (kinder $=$ anak, garten $=$ taman $)$ atau Taman

6 Abdullah Nasih Ulwan. 2015. Tarbiyatul Aulad Fil Islam: Menggilap Sinar Pribadi Anak). (Kuala Lumpur: BS Print (M) SDN BHD. 2015). hlm. 521
Kanak-Kanak, muncul setelah Friedrich Wilhelm Frobel (1782-1852) seorang ahli pendidikan, mendirikan Kinder-Garten di Jerman pada tahun 1837. Di Indonesia sendiri Taman Kanak Kanak baru dikenal pada tahun 1922 setelah perguruan nasional Taman Siswa yang didirikan oleh Ki Hajar Dewantara membuka sekolah bagi anak kecil dibawah umur 7 tahun, yang dinamakan 'Taman Lare' atau Taman Anak, yang kelak berubah nama menjadi "Taman Indria".

Muazar Habibi (2015: 112), menyebutkan bahwa PAUD adalah pemberian upaya untuk menstimulasi, membimbing, mengasuh dan pemberi kegiatan pembelajaran yang menghasilkan kemampuan dan keterampilan pada anak (kompetensi). ${ }^{7}$ Pendidikan anak usia dini (PAUD) adalah jenjang pendidikan sebelum jenjang pendidikan dasar yang merupakan suatu upaya pembinaan yang ditujukan bagi anak sejak lahir sampai dengan usia enam tahun yang dilakukan melalui pemberian rangsangan pendidikan untuk membantu pertumbuhan dan perkembangan jasmani dan rohani agar anak memiliki kesiapan dalam memasuki pendidikan lebih lanjut, yang diselenggarakan pada jalur formal, nonformal, dan informal.

Pendidikan anak usia dini yang penyelenggaraannya sebelum jenjang pendidikan dasar, formal, dan/atau informal (Pasal 28 UU RI Nomor 20 Tahun 2003), tidak kalah pentingnya dengan pendidikan jenjang di atasnya. Pendidikan prasekolah menjadi dasar pendidikan tingkat dasar dan tingkat menengah. Pendidikan nilai, melalui penanaman nilai-nilai dasar humanis religius secara informal memang menjadi kewajiban keluarga dalam bentuk sosialisasi primer, secara

7 Muazar Habibi. Analisis Kebutuhan Anak Usia Dini. (Yogyakarta: CV. Budi Utama. 2015). hlm. 112. 
umum berlangsung sejak anak lahir hingga masuk TK. Penanaman nilai-nilai luhur yang fungsi-nya mendasari perilaku anak di luar rumah telah dilaksanakan oleh keluarga. Pendidikan nilai di keluarga didasari cinta kasih dan ikatan batin orangtua dengan anaknya. Anak yang fitrahnya suci dalam keluarga merupakan amanah Allah SWT kepada orangtuanya. Sebagai khalifah Allah di bumi anak harus cerdas dan berakhlak mulia, karena itu membutuhkan pendidikan nilai untuk mengembangkan akhlak, iman, keilmuan, dan keterampilan sosialnya

Pendidikan anak usia dini merupakan salah satu bentuk penyelenggaraan pendidikan yang menitikberatkan pada peletakan dasar ke arah pertumbuhan dan perkembangan fisik (koordinasi motorik halus dan kasar), kecerdasan (daya pikir, daya cipta, kecerdasan emosi, kecerdasan spiritual), sosio emosional (sikap dan perilaku serta agama) bahasa dan komunikasi, sesuai dengan keunikan dan tahap-tahap perkembangan yang dilalui oleh anak usia dini.

Ada dua tujuan secara umum dari diselenggarakannya pendidikan anak usia dini, yaitu:

a. Tujuan utama: untuk membentuk anak Indonesia yang berkualitas, yaitu anak yang tumbuh dan berkembang sesuai dengan tingkat perkembangannya sehingga memiliki kesiapan yang optimal di dalam memasuki pendidikan dasar serta mengarungi kehidupan di masa dewasa.

b. Tujuan penyerta: untuk membantu menyiapkan anak mencapai kesiapan belajar (akademik) di sekolah.

Dengan disahkannya Undang-Undang Nomor 20 Tahun 2003 tentang Sistem Pendidikan Nasional, secara yuridis formal Indonesia telah memiliki pijakan yang lebih kuat untuk melaksanakan Pendidikan Anak
Usia Dini dalam undang-undang tersebut dikemukakan bahwa, pendidikan usia dini diselenggarakan sebelum jenjang pendidikan dasar melalui jalur pendidikan formal, non formal dan atau informal. Pendidikan anak usia dini pada jalur pendidikan formal berbentuk Taman Kanak-Kanak (TK), Raudhatul Athfal (RA) atau bentuk lain yang sederajat. Pendidikan anak usia dini pada pada jalur pendidikan nonformal berbentuk kelompok bermain, Taman Penitipan Anak atau bentuk lain yang sedarajat. Pendidikan Anak Usia Dini pada jalur pendidikan informal berbentuk pendidikan keluarga atau pendidikan yang diselenggarakan oleh lingkungan. ${ }^{8}$

\section{Pengertian Nilai-Nilai Dasar Islam dan Internalisasi Nilai-Nilai Keislaman}

Menurut Nurcholis Madjid (dalam Ahmad Baso, 2006: 211) yang dimaksud 'nilai-nilai Islam' ialah setiap nilai yang sejalan dengan kemanusian, atau fitri atau hanif dengan dilandasi taqwa kepada Allah. Nilainilai akan dianggap Islami apabila ia, secara asasi tidak bertentangan dengan iman dan taqwa dan adalah baik menurut kemanusiaan, sesuai dengan perkembangannya. ${ }^{9}$ Nilai-nilai dasar adalah nilai yang tak berubah sepanjang masa nilai-nilai budaya atau nilai-nilai duniawi yang senantiasa berubah. Selanjutnya Sarjono (2005: 136) menyatakan, ketika nilai telah dilekatkan pada sebuah sistem, maka ia akan mencerminkan paradigma, jati diri dan grand concept dari sistem tersebut. Oleh karena itu, nilai-nilai dasar pendidikan Islam bermakna konsep-konsep pendidikan yang

8 Tim Pengembang Ilmu Pendidikan FIP-UPI. 2007. Ilmu dan Aplikasi. (Bandung: PT. Imperial Bhakti Utama, 2007). hlm. 113.

9 Ahmad Baso. NU Studies: Pergolakan Pemikiran antara Fundamentalisme Islam dan Fundamentalisme Noe Liberal. (Jakarta : Penerbit Erlangga. 2006). hlm. 211. 
dibangun berdasarkan ajaran Islam sebagai landasan etis, moral dan operasional. Dalam konteks ini, nilai-nilai dasar pendidikan Islam menjadi pembeda dari model pendidikan lain, sekaligus menunjukkan karakteristik khusus. ${ }^{10}$ Fungsi nilai dalam ranah pendidikan pada dasarnya adalah membantu peserta didik untuk mengembangkan pribadi yang lebih manusiawi sesuai kodrat dan fitrahnya sebagai manusia. Dari pencapaian nilai inilah masyarakat akan memperoleh pribadi-pribadi yang handal dalam bidang akademis, keterampilan, keahlian, sekaligus memiliki watak atau keutamaan yang luhur.

Berdasarkan pendapat di atas maka, pendidikan yang dijalankan atas nilai dasar Islam mempunyai dua orientasi. Pertama, ketuhanan, yaitu penanaman rasa takwa dan pasrah kepada Allah sebagai Pencipta yang tercermin dari kesalehan ritual atau nilai sebagai hamba Allah. Kedua, kemanusiaan, menyangkut tata hubungan dengan sesama manusia. Lingkungan dan makhluk hidup yang lain yang berkaitan dengan status manusia sebagai Khalifah Allah fi al-ardhi.

Nilai dasar dalam Islam juga seringkali disebut dengan nilai dasar ubudiyah, moralitas/akhlaqul karimah, dan nilai dasar nizhamiyah/kedisiplinan. Nilai dasar ubudiyah meliputi aktivitas manusia sebagai hamba Allah SWT dan selaku khafilah-Nya di muka bumi. Sedangkan nilai dasar moralitas/ akhlaqul karimah merupakan inti ajaran Islam yang dibawa oleh Rasulullah SAW, yang tidak lain untuk memperbaiki akhlak manusia menjadi lebih baik dan nilai dasar nizhamiyah yang membentuk manusia untuk berperilaku taat pada aturan yang telah dibuat oleh Allah SWT.

10 Sarjono. Nilai-Nilai Dasar Pendidikan Islam dalam Jurnal Pendidikan Agama Islam Vol. 11, No. 2, 2005
Dalam konteks ini, ada beberapa nilai dasar yang dapat dimunculkan oleh beberapa ahli, antara lain sebagaimana yang diungkapkan oleh Sarjono (2005: 140) bahwa nilainilai dasar Islam terdiri dari (a) Keimanan dan ketaqwaan, (b) Penghargaan terhadap eksistensi manusia dengan segala potensinya, (c) Mengedepankan prinsip kebebasan dan kemerdekaan, dan (d) Tanggung jawab sosial. Sedangkan menurut Ali Masykur Musa (2014: 31) menyatakan bahwa, nilai-nilai dasar Islam adalah nilai-nilai yang bersifat universal tentang keadilan, kejujuran, persmaan, persaudaraan, amanah dan musyawarah. Sehingga, berdasarkan argument tersebut dapat dikemukakan bahwa universalisme ajaran Islam telah memuat prinsip-prinsip dasar mengenai hubungan-hubungan sosial, termasuk demokrasi. Namun Yusuf Noor (dalam Abdul Rahman, 1997: 176) mengingatkan bahwa dalam Islam dikenal dua buah nilai, yang pertama nilai-nilai dasar (basic values) dan nilai-nilai tambahan (secondary values). Yang diutamakan dalam hal ini adalah nilainilai dasar sedangkan nilai-nilai tambahan hanya berfungsi melengkapi. ${ }^{11}$

Secara umum pendidikan anak usia dini khususnya pada anak-anak di sekolah Islam adalah membangun individu yang berkepribadian Islami berdasarkan pada pada al-Quran dan As-Sunah. Sehingga dari tujuan ini akan tebentuk individu yang berakhlakul kharimah, serta memiliki kecerdasan emosional dan spiritual (religius), konsistensi (istiqamah), kerendahan hati (tawadhu), totalitas (kaffah), keseimbangan (tawazun), integritas dan penyempurnaan (ihsan). Kebutuhan pendidikan nilai, melalui penanaman nilainilai dasar keislaman pada anak usia dini kel-

11 Abdul Rahman Haji Abdullah. Pemikiran Islam di Malaysia: Sejarah dan Aliran. (Jakarta : Gema Insani Press. 1997). hlm. 176. 
uarga perkotaan hendaknya dapat dilakukan pada TK dan PAUD yang mengusung tema Islam ataupun yang mengaku berlandaskan konsep dasar Islam. Pendidikan seperti ini sangatlah cocok dengan Indonesia, mengingat mayoritas penduduk Indonesia memang beragama Islam, sehingga sistem pendidikan Islam yang mampu mengembangkan pribadi dalam membentuk akhlakul karimah, baik secara individual maupun sosial, seharusnya menjadi tujuan utama setiap institusi pendidikan di Indonesia.

Penanaman nilai sosial dalam diri peserta didik, dilakukan dengan tujuan diterimanya nilai-nilai sosial keagamaan dan aqidah tertentu oleh peserta didik, berubahnya nilai-nilai peserta didik yang tidak sesuai dengan nilai-nilai sosial keagamaan dan aqidah yang tidak diinginkan. Namun disadari atau tidak pendekatan penanaman nilai pada hakekatnya juga untuk mencapai sebuah konsep pendidikan yang mengandung empat pilar pendidikan, yakni : (1) belajar mengetahui (learning to know), (2) belajar berbuat (learning to do), (3) belajar menjadi diri sendiri (learning to be), dan (4) belajar hidup bersama (learning to live together).

Konsep kepribadian Islam merupakan penampilan makhluk mulia yang memiliki struktur kompleks, meliputi jasmani, ruhani, dan nafsani. Hal ini sejalan dengan pandangan dengan teori Bloom (1956) yang menyatakan bahwa, perilaku manusia dapat berubah setelah adanya pembelajaran. Pembelajaran akhlak mulia merubah perilaku anak menjadi lebih baik. Perubahan perilaku meliputi kawasan (domain) kognitif, afektif, dan psikomotor. Domain kognitif terdiri dari aspek intelektual atau pikiran yang merupakan domain dasar, terdiri dari pengetahuan, bentuknya pada anak adalah mengetahui halhal yang berkaitan dengan Allah SWT, Kitab al-quran, Malaikat, Nabi dan Rasul, shalat wajib, shalat sunnah, shalat berjama'ah, dan seterusnya. Domain afektif mengait dengan aspek emosional, minat dalam berkomunikasi sosial, santun saat bicara, mau meminta maaf jika berbuat salah, mau memberi maaf jika ada teman yang berbuat salah pada dirinya. Domain psikomotor, mengait dengan perkembangan keterampilan fisik (menggambar, mewarnai, menggunting, menempel, dan sebagainya). Dengan kata lain perubahan perilaku anak semakin baik di sekolah dan di rumah setelah mendapatkan penanaman nilainilai dasar humanis religius. Perubahan perilaku anak di sekolah meliputi : (a) perilaku dalam aqidah, (b) perilaku dalam akhlak, (c) perilaku dalam ibadah, (d) perilaku dalam dimensi sosial, emosional, dan kemandirian. Perubahan perilaku anak di rumah ditunjukkan dengan: (a) lebih memperhatikan dan mendengarkan kata-kata orangtua, (b) dapat mengucapkan dan menjawab salam secara Islam dengan benar, (c) dapat membedakan pakaian yang menutup aurat dan tidak menutup aurat, (d) dapat berdoa sendiri.

\section{MASYARAKAT PERKOTAAN DAN DINAMIKA PAUD DALAM PENANAMAN NILAI-NILAI DASAR} ISLAMI

Masyarakat perkotaan dalam Islam merujuk pada pengertian masayarakat madani. Hal ini sebagaimana diungkapkan oleh Mulyadhi Kartanegara (2007: 74), yang menyatakan bahwa kata "madani" tentu saja berkaitan dengan kata Madinah yang berarti "kota". Masyarakat madani biasa berarti masyarakat kota atau perkotaan. Meskipun dalam hal ini istilah "kota" tidak merujuk semata-mata pada letak geografis, namun merujuk pada karakter atau sifat-sifat tertentu "yang cocok untuk penduduk sebuah 
kota”. Oleh karena itu kata urban yang kita terjemahkan kota, juga berkaitan erat dengan kata "urbane" yang artinya "memiliki sifat lembut (refined), halus, terpoles (polished) atau sopan (polite). ${ }^{12}$

Berdasarkan pendapat di atas, sudah sepantasnya masyarakat kota yang jika dikaitkan dengan kata civilized dalam Bahasa Inggris yang artinya "memiliki peradaban" (civilization) dan dalam bahasa Arab dikaitkan dengan kata tamadun yang juga berarti "peradaban" atau "kebudayaan tinggi". Mencermikan sebuah peradaban yang positif dan membawa pada kemajuan secara moral dan intelektual. Namun, kenyataan saat ini menunjukkan sebaliknya dan jauh dari harapan. Sehingga melalui pendidikan sejak dini diharapkan akan terbentuk generasi masyarakat perkotaan yang benar-benar bersifat madani.

Konsep perkotaan di atas sepertinya belum terbentuk secara merata pada masyarakat modern saat ini. Bahkan, keluarga perkotaan merupakan keluarga dalam proses adaptasi terhadap kehidupan modern. Keluarga perkotaan termasuk tipologi yang tidak memperlihatkan ikatan kekerabatan yang kuat, mereka mulai terbebas dari ikatan keluarga dalam arti luas dan terkesan mengisolasi dirinya. Meskipun demikian, sebagian besar orangtua dari anak usia dini, keluarga perkotaan tetap mendambakan anaknya berkepribadian. Kepribadian dalam studi Islam lebih dikenal dengan istilah syakhshiyah, berasal dari kata syakhshun yang artinya kepribadian. Kepribadian menurut Islam adalah integrasi sistem kalbu, akal, dan nafsu manusia yang menimbulkan perilaku (beriman dan beramal shalih).

12 Mulyadhi Kertanegara. Mengislamkan Nalar : Sebuah Respons Terhadap Modernitas. (Jakata : Penerbit Erlangga. 2007). hlm. 73-74.
Sebagaimana telah dijelaskan di awal, usia dini merupakan periode awal yang paling penting dan mendasar dalam sepanjang rentang pertumbuhan dan perkembangan manusia. Pada masa ini terdapat sebuah periode yang menjadi ciri khas yaitu the golden ages atau periode keemasan. Banyak konsep dan fakta yang ditemukan memberikan penjelasan periode keemasan pada masa usia dini, di mana semua potensi anak berkembang dengan cepat. Beberapa konsep yang disandingkan dengan masa anak usia dini adalah masa eksplorasi, masa identifikasi/imitasi, masa peka, masa bermain dan masa trozt alter 1 (masa membangkang tahap 1).

Anak usia dini pada keluarga perkotaan adalah anak dari keluarga yang tinggal di wilayah perkotaan dan sekitarnya. Orangtua di perkotaan cenderung merasa banyak diuntungkan dengan adannya Taman KanakKanak yang bersifat full day school. Adapun program full day school yang dimaksud adalah program sekolah di mana proses pembelajaran dilaksanakan sehari penuh di sekolah. Hasil penelitian Cryan (dalam Seniati Sutarmin, dkk, 2014) telah membuktikan efek yang luas dalam pendidikan anak usia dini dengan sistem full day school, yang mampu menjadikan anak memiliki kedekatan dengan guru, kelebihan dalam perilaku yang positif, kesuksesan akademik, kemandirian dalam belajar, produktivitas dalam kerja, dan pengendalian emosi/rasa percaya diri. Sistem full day school juga dianggap cukup efektif untuk perkembangan anak usia dini, karena mampu memberikan keteladanan dengan mental persaudaraan (brotherhood), persahabatan (friendship), dan dengan metode yang dialogis, secara klasikal dan individual, dalam suasana yang menyenangkan. ${ }^{13}$

13 Seniati Sutarmin, dkk. Penanaman Nilai-Nilai 
Meskipun disisi lain belum semua TK full day school di kota dapat melaksanakan pendidikan nilai bagi anak usia dini seperti yang dimaksudkan, karena motivasi pihak penyelenggara TK IT full day school banyak yang memperhitungkan untung dan rugi, bukan semata-mata mengutamakan keberhasilan pendidikan nilai.

Bisnis TPA, PG, dan TK IT full day school di kota-kota besar cenderung dianggap bisnis jasa yang cukup menguntungkan. Hal ini ditunjukkan dengan bermunculannya TK maupun PAUD sejenis yang terus bertambah, dan rata-rata kelas yang dimiliki juga hampir dipastikan selalu penuh. Persaingan ini memicu perbaikan fasilitas-fasiltas yang dimiliki lembaga pendidikan agar mampu memenangkan persaingan untuk mendapatkan peserta didik, karena menjelang tahun ajaran baru mereka harus berlomba-lomba membujuk keluarga perkotaan agar memilih program yang ditawarkannya, melalui promosi, diantaranya dengan memasang spanduk di berbagai sudut kota. Fenomena tersebut menimbulkan juga menimbulkan beberapa masalah terutama berkaitan dengan kualitas peserta didik yang akan dihasilkan.

Dengan kebijakan full day school, waktu yang dihabiskan oleh anak-anak akan lebih banyak dilakukan di lingkungan sekolah dari pada di rumah. Pada sisi tersebut full day school memang memiliki dampak bagi perkembangan anak, terutama berkaitan dengan rendahnya sisi sosial emosional kesempatan dan kemampuan anak untuk berinteraksi dengan lingkungan rumah dan sekitarnya. Anak juga menjadi terlalu lelah karena berkurang waktu istirahatnya. Anak memang dia-

Dasar Humanis Religius Anak Usia Dini Keluarga Perkotaan di TK Islam Terpadu. Jurnal Pembangunan Pendidikan: Fondasi dan Aplikasi Volume 2, Nomor 2, 2014. hlm. 158-159 jarkan untuk bersosialisasi, bergaul dengan teman dan gurunya di sekolah, tetapi sosialisasi di sekolah dan di rumah tentu memiliki aturan yang berbeda. Padahal bersosialisasi dan bermain dengan keluarga dan lingkungan sekitar (teman sebaya/tetangga) juga penting bagi perkembangan sosial emosional anak.

Disisi lain kegiatan ini secara tidak langsung telah memutus mata rantai hubungan sosial dan psikis antara anak dan orang tua. Nilam Widyarini (2009: 12), menyatakan bahwa :

Mereka juga tidak menyadari bahwa dalam pola yang lebih banyak menuntut terhadap anak ini telah mengikis kehangatan hubungan dengan anak. Anak tidak menemukan suasana yang memungkinkan untuk mengekspresikan pikiran atau perasaaannya. Padahal kehangatan, dalam hubungan orangtua-anak merupakan prasyarat bagi kesejahteraan psikologis baik anak maupun orangtua. ${ }^{14}$

Pilihan orang tua dalam memasukan anak ke taman kanak-kanak maupun TK yang berbasis full day school menjadikan mereka tidak kritis terhadap penyelengaraan kegiatan sekolah, tidak banyak orangtua yang mempertimbangkan tentang apa dan bagaimana konsep yang melandasi kegiatan pembelajaran di lembaga tersebut, metode dan media apa yang digunakan sekolah dalam mendidik anak, dan sejauh mana TK tersebut telah berhasil melaksanakan penanaman nilainilai dasar keislaman bagi peserta didiknya. Bahkan Meskipun secara ekonomis biaya yang harus ditanggung orangtua akan lebih mahal dengan memasukan anak di usia dini dibandingkan dengan TK Islam biasa.

14 Nilam Widyarini. Relasai Orang Tua dan Anak. (Jakarta : Elex Media Komutindo. 2009). hlm. 12 
Keluarga perkotaan cenderung lebih memilih menyekolahkan anaknya di TK IT Full Day School. Sulistyaningsih (dalam Seniati Sutarmin, 2014) menyatakan bahwa TK full day school yang berhasil memiliki tiga faktor pendukung utama, yaitu: faktor kurikulum, keterlibatan orangtua, dan kualitas program yang dilaksanakan. Namun dalam kenyataan masih banyak orangtua perkotaan belum memahami kurikulum TK, belum banyak ikut berperan pada kegiatan TK, dan belum banyak yang terlibat secara langsung pada program dan pelaksanaan penanaman nilai-nilai dasar humanis religius. Kebanyakan orangtua tidak memasalahkan program, pelaksanaan dan hasil penanaman nilai-nilai dasar humanis religius. ${ }^{15}$

Persoalan di atas sudah semestinya dapat diselesaikan dengan hubungan yang baik antara guru dan orangtua. Sebagaimana dikemukakan Reni Akbar Hawadi (2001: 97), yang menyatakan bahwa :

Hubungan yang positif antara sekolah dan rumah merupakan kontribusi yang penting di dalam presetasi anak sekolah. Untuk membina hubungan positif bukan berarti menunggu adanya problem dari anak. Baik guru maupun orang tua dapat melakukan komunikasi langsung dua arah, timbal balik dan saling mempercayai. Dalam hal ini guru dapat saja menelepon orang tua, namun pada kelas yang lebih besar, komunikasi yang memungkinkan adalah melalui surat. Inti utamanya adalah agar orang tua mengetahui bahwa guru kelas, guru bersedia dan dapat dihubungi oleh orangtua. ${ }^{16}$

15 Seniati Sutarmin, dkk. Op. Cit. Hlm. 158-159.

16 Reni Akbar Hawadi. Psikologi Perkembangan Anak: Mengenal Sifat, Bakat dan Kemampuan Anak. Jakarta : Grasindo. 2001). hlm. 97.
Selanjutnya dinamika lain pada penyelenggaran TK dan PAUD di daerah perkotaan, adalah adanya kesenjangan. Pada masyarakat perkotaan dan pedesaan pemenuhan kebutuhan yang substansial terhadap pendidikan anak usia dini terbilang relatif sama. Namun disisi lain kebutuhan ini memiliki kesenjangan yang cukup signifikan, hal ini sebagaimana diungkapkan oleh Mohammad Ali (2009: 241), yang menyebutkan bahwa:

Kesenjangan terjadi di jenjang Pendidikan Anak Usia Dini (PAUD). Akses anak usia dini terhadap layanan pendidikan dan perawatan melalui pendidikan anak dini, masih terbatas dan tidak merata. Dari sekitar 28, 2 juta anak usia $0-6$ tahun, yang memperoleh layanan PAUD adalah baru 7, 2 juta $(25,3 \%)$. Untuk anak usia $5-6$ tahun yang jumlahnya sekitar 8, 14 juta anak, baru sekitar 2, 63 juta anak (atau sekitar 32, $36 \%$ ) yang memperoleh layanan pendidikan di Taman Kanak-Kanak (TK) atau raudhatul Anfhal (RA). ${ }^{17}$

Dinamika kesenjangan dan pemerataan PAUD dan TK di atas juga ditambah dengan kesenjangan terkait pembayaran dan akses kependidikan bagi guru TK dan PAUD jika dibandingkan dengan mereka yang berstatus guru di sekolah. Meskipun berdasarkan status mereka adalah sama-sama merupakan pendidik. Namun pada jenjang karir dan kesempatan berkarya di lingkungan yang lebih global, mereka masih kurang mendapat perhatian dan pengembangan.

17 Mohammad Ali. Pendidikan Untuk Pembangunan Nasional: Menuju Bangsa Indonesia yan Mandiri dan Berdaya Saing Tinggi. Jakarta: Grasindo. 2009). hlm. 241. 


\section{PENUTUP}

Penanaman nilai-nilai dasar keislaman pada anak perlu dilakukan sejak dini yaitu dengan menawarkan suatu alternatif proses penanaman nilai-nilai dasar kepribadian Islami melalui pendidikan nilai yang terintegrasi dengan berbagai kegiatan pendidikan di Taman Kanak-Kanak (TK) atau Pendididikan Anak Usia Dini (PAUD). Selain itu lembaga pendidikan anak usia dini beserta orangtua hendaknya dapat bekerjasama sebagai mitra dalam membentuk kepribadian Islami dan akhlak mulia.

Selain itu, penanaman nilai-nilai dasar keislaman bagi anak usia dini di keluarga perkotaan perlu ditingkatkan, agar memperoleh hasil yang optimal termasuk dengan menyiapkan kurikulum yang dalam bab dan subbabnya terkandung penanaman nilai-nilai dasar keislaman dengan metode yang sesuai dengan perkembangan anak, situasi, dan kondisi kekinian. Selain itu pendidikan anak usia dini perlu dilaksanakan secara lebih kreatif dan inovatif, tanpa mengesampingkan tugas pokok lembaga terhadap proses belajar mengajar yang sifatnya rutin, intelektual, dan psikomotorik.

Pada sisi lain para pembuatan kebijakan pendidikan perlu mendukung penanaman nilai-nilai dasar keislaman yang berlaku di tingkat pendidikan anak usia dini baik secara materil dan non materil. Sehingga pendidikan yang ada dapat direncanakan dan dievaluasi serta diawasi secara bersama guna memperoleh akan lebih optimal.

\section{DAFTAR PUSTAKA}

Abdullah, Abdul Rahman Haji. 1997. Pemikiran Islam di Malaysia: Sejarah dan Aliran. Jakarta : Gema Insani Press.
Abidin, Danial Zainal. 2007. Al-Qur'an for Life Exellence: Tips-Tips Cemerlang dari Al-Qur'an. Jakarta. PT. Mizan Publika.

Ali, Mohammad. 2009. Pendidikan Untuk Pembangunan Nasional: Menuju Bangsa Indonesia yan Mandiri dan Berdaya Saing Tinggi. Jakarta: Grasindo.

Anshor, Maria Ulfah \& Abdullah Ghalib. 2010. Parenting With Love : Panduan Islami Mendidik Anak Penuh Cinta dan Kasih Sayang. Jakarta: PT. Mizan Pustaka.

Baso, Ahmad. 2006. NU Studies: Pergolakan Pemikiran antara Fundamentalisme Islam dan Fundamentalisme Noe Liberal. Jakarta : Penerbit Erlangga.

Brooks, Jane. 2011. The Process of Parenting. Terj. Rahmat Fajar. Yogyakarta: Pustaka Pelajar.

Faozan, Akhmad. 2009. 500 Kelalaian dalam Shalat. Jakarta : Qultum Media.

Habibi, Muazar. 2015. Analisis Kebutuhan Anak Usia Dini. Yogyakarta: CV. Budi Utama.

Hawadi, Reni Akbar. 2001. Psikologi Perkembangan Anak: Mengenal Sifat, Bakat dan Kemampuan Anak. Jakarta : Grasindo.

Kertanegara, Mulyadhi. 2007. Mengislamkan Nalar: Sebuah Respons Terhadap Modernitas. Jakata: Penerbit Erlangga.

Sarjono. Nilai-Nilai Dasar Pendidikan Islam. Jurnal Pendidikan Agama Islam 
Vol. 11, No. 2, 2005.

Sutarmin, Seniati dkk. Penanaman Nilai-

Nilai Dasar Humanis Religius

Anak Usia Dini Keluarga

Perkotaan di TK Islam Terpadu.

Jurnal Pembangunan Pendidikan:

Fondasi dan Aplikasi Volume 2,

Nomor 2, 2014.

Tim Pengembang Ilmu Pendidikan FIP-UPI. 2007. Ilmu dan Aplikasi. Bandung : PT. Imperial Bhakti Utama.

Ulwan, Abdullah Nasih. 2015. Tarbiyatul Aulad Fil Islam: Menggilap Sinar Pribadi Anak. Kuala Lumpur: BS Print (M) SDN BHD.

Widyarini, Nilam. 2009. Relasai Orang Tua dan Anak. Jakarta : Elex Media Komutindo. 